https://doi.org/10.17816/MAJ191S196-98

\title{
ESPECIALLY CELLULAR IMMUNITY IN PATIENTS WITH TRAUMATIC BRAIN INJURY OF DIFFERENT SEVERITY IN ACUTE PERIOD
}

\author{
A.O. Norka ${ }^{1}$, R.N. Kuznetsova ${ }^{1,3}$, S.V. Kudryavtsev ${ }^{1,4}$, S.N. Kovalenko ${ }^{5,6}$, \\ M.K. Serebriakova ${ }^{4}$ S.V. Vorobyev ${ }^{2}$ \\ ${ }^{1}$ Pavlov First Saint Petersburg State Medical University, Saint Petersburg, Russia; \\ ${ }^{2}$ Saint Petersburg State Pediatric Medical University, Saint Petersburg, Russia; \\ ${ }^{3}$ Saint Petersburg Pauster Institute, Saint Petersburg, Russia; \\ ${ }^{4}$ Institute of Experimental Medicine, Saint Petersburg, Russia; \\ ${ }^{5}$ S.M. Kirov Military Medical Academy, Saint Petersburg, Russia; \\ ${ }^{6}$ City Hospital No. 26, Saint Petersburg, Russia
}

\section{ОСОБЕННОСТИ КЛЕТОЧНОГО ИММУНИТЕТА У ПАЦИЕНТОВ С ЧЕРЕПНО-МОЗГОВОЙ ТРАВМОЙ РАЗЛИЧНОЙ СТЕПЕНИ ТЯЖЕСТИ В ОСТРОМ ПЕРИОДЕ ЗАБОЛЕВАНИЯ}

\author{
А.О. Норка ${ }^{1}$ Р.Н. Кузнецова ${ }^{3}$, И.В. Кудрявцев ${ }^{4}$, С.Н. Коваленко ${ }^{5,}$, \\ М.К. Серебрякова ${ }^{4}$, С.В. Воробьев ${ }^{2}$ \\ ${ }^{1}$ ФГБОУ ВО «Первый Санкт-Петербургский государственный медицинский университет \\ им. акад. И.П. Павлова», Санкт-Петербург; \\ 2 ФГБОУ ВО «Санкт-Петербургский государственный педиатрический медицинский университет», \\ Санкт-Петербург; \\ ${ }^{3}$ ФБУН «Научно-исследовательский институт эпидемиологии и микробиологии им. Пастера», Санкт-Петербург; \\ ${ }^{4}$ ФГБНУ «Институт экспериментальной медицины», Санкт-Петербург; \\ ${ }^{5}$ ФГБВОУ ВПО «Военно-медицинская академия им. С.М. Кирова» Минобороны России, Санкт-Петербург; \\ ${ }^{6}$ СПб ГБУЗ «Городская больница № 26, Санкт-Петербург
}

norka-anna@mail.ru

Currently, it is known that in response to brain damage a reaction from the immune system is triggered, but its role in the formation of clinical manifestations remains a little-studied problem to date. Using multicolor cytometric analysis, a study was conducted to determine the number of Th1-, Th2-, Tfh- and Th17-cells among CD45RA-negative $\mathrm{CD}^{+} \mathrm{CD}^{+}$cells in a group of patients with mild TBI (M-TBI, $\left.n=20\right)$ and with moderate to severe TBI (MS-TBI, $n=16)$ and a group of conditionally healthy donors $(n=30)$. The imbalance between Th2 cells and Th17 cells was found in patients with TBI in the acute period, which probably predetermines the course of the disease and the development of complications.

Keywords: flow cytometry; traumatic brain injury (TBI); CD45RA-negative (memory) $\mathrm{CD}^{+} \mathrm{CD}^{+} 1 \mathrm{lym}-$ phocytes.

В настоящее время известно, что в ответ на повреждение головного мозга запускается реакция иммунной системы, но его роль в формировании клинических проявлений до настоящего времени. С применением многоцветного цитометрического анализа проведено исследование по определению количества Th1-, Th2-, Tfh- and Th17- клеток среди CD45RA-negative CD3 ${ }^{+} \mathrm{CD}^{+}$Th в группе больных с сотрясением головного мозга $(n=20)$ и ушибом головного мозга $(n=16)$ и группе условно здоровых доноров $(n=30)$. Выявлен дисбаланс между Th2-клеток и Th17-клеток у пациентов с ЧМТ в острый период, что возможно предопределяет течения заболевания и развития осложнений.

Ключевые слова: проточная цитофлуометрия; черепно-мозговая травма (ЧМT); CD45RA-negative (памяти) $\mathrm{CD}^{+} \mathrm{CD} 4^{+}$лимфоциты.

Introduction. The use of structural neuroimaging techniques often does not allow timely assessment of the severity of the brain injury that occurred. This is characteristic, first of all, for traumatic brain injury (TBI) of mild severity, at which a submicroscopic level of damage is observed. This provision determines the need to find new methods for differential diagnosis of severe TBI and predict the risk of development of consequences. One of these promising areas is the study of the immune status or subpopulation composition of peripheral blood lymphocytes of patients in the acute period of injury. Currently, it is known that the response of the immune system is triggered in response to brain damage, but its role in the formation of individual clinical manifestations remains a problem that has not been sufficiently studied [1]. Reactions from the immune system, which develop after a brain injury and, possibly, are directed against their own antigens, in the early period of the disease are related to damage to the nervous tissue. However, according to the latest available data, they are subsequently able to stimulate the processes of repair and regeneration in the brain tissue [2]. To analyze the nature of changes during TBI, flow cytofluorometry was 
a

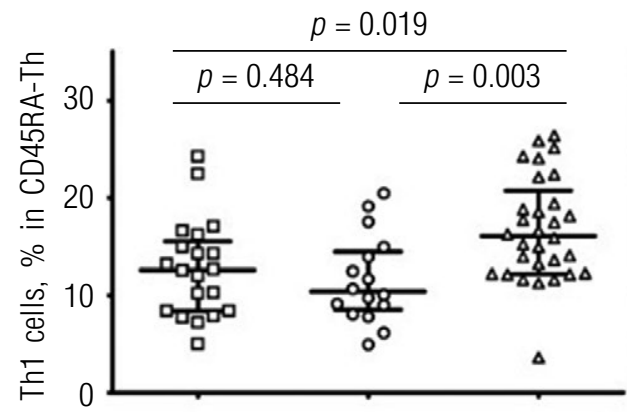

c

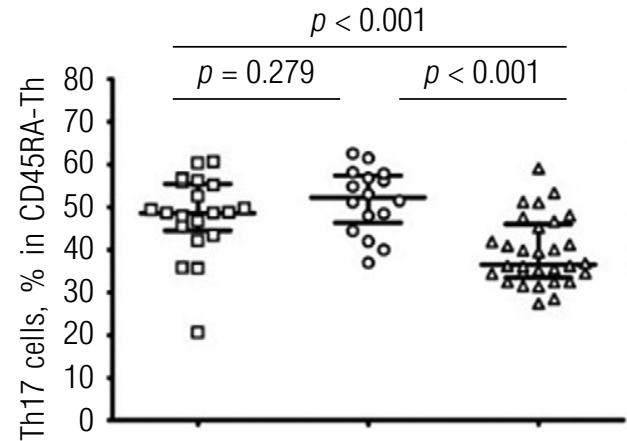

b

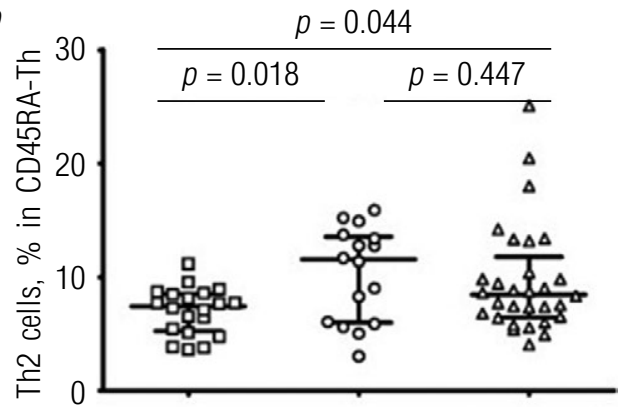

d

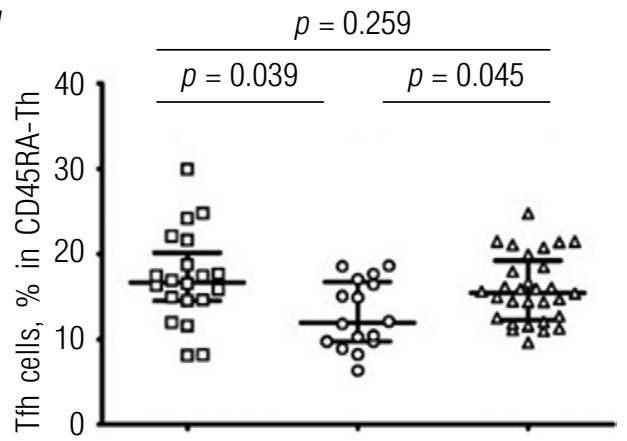

Figure. Comparative analysis of main circulating Th subsets in M-TBI ( $n=20$, white square) и MS-TBI ( $n=16$, white circus) и healthy control ( $n=30$, white triangle)

used to examine T-lymphocyte subpopulations in patients with brain injury.

Material and methods. Blood samples in 16 patients with diagnosis mild TBI (M-TBI) and 20 patients with moderate to severe TBI (MS-TBI) between the ages of 18 and 45 years. The severity of TBI was assigned according to established criteria [3].

The combination of monoclonal antibodies, approach design and "gating strategy" allowed to identify main Th subsets in patients and healthy control peripheral blood were described previously [4]. Sample acquisition was performed using a Navios flow cytometer (Beckman Coulter, Inc., USA). Th subsets size (the percentage) within CD45RAnegative (memory) $\mathrm{CD}^{+} \mathrm{CD}^{+}$lymphocytes are given in medians and quartile ranges $\left(\operatorname{Med}\left(Q_{25} ; Q_{75}\right)\right)$. The statistical comparisons of data between TBI patients and healthy controls were performed using the Mann-Whitney $U$-test. Differences were considered significant when $p$ values were $<0.05$. All of the statistical analysis of data was carried out with GraphPad Prizm 6 (GraphPad Software, USA).

Result and discussion. The results shown in figure. The comparison of these different Th subsets between patients and control group indicated significantly lower Th1 $(p=0.019 ; p=0.003)$ and sig- nificantly higher Th17 $(p<0.001 ; p<0.001)$ with patients of M-TBI and M-TBI if compared with healthy controls. Also, we did observe significant lower in Th2 cells with patients of M-TBI if compared with healthy controls. As for the Tfh-cells, they were change only slightly, but there are significant changes $(p=0.039)$ between the groups with $\mathrm{M}-$ and MS-TBI.

The revealed changes in the CD45RA-negative $\mathrm{CD}^{+}{ }^{+} \mathrm{CD}^{+}$cell population in patients with $\mathrm{TBI}$ allowed to raise the question of the significance of determining these cells subpopulations, which may be a predictor of the course of TBI in the acute period.

Scatter plots $a, b, c$ and $d$ showing the percentages Th1 (CXCR5 ${ }^{-} \mathrm{CXCR}^{+}{ }^{+} \mathrm{CCR} 6^{-}$ CCR4), Th2 (CXCR5 ${ }^{-} \mathrm{CXCR}^{-}{ }^{-} \mathrm{CCR} 6^{-} \mathrm{CCR} 4^{+}$), Th17(CXCR5 ${ }^{-}$CXCR $^{-}{ }^{-} \mathrm{CCR}^{+}{ }^{+} \mathrm{CCR} 4^{-}$) and $\mathrm{Tfh}$ (CXCR5 ${ }^{+} \mathrm{CXCR}^{-} \mathrm{CCR}^{-} \mathrm{CCR}^{-}{ }^{-}$), respectively, in the peripheral blood samples for TBI and healthy control subjects. Numbers represent the percentage of the indicated Th subset among total CD45RA-negative $\mathrm{CD}^{+} \mathrm{CD} 4^{+}$cell population. Each dot represents individual subjects, and horizontal bars represent the group medians and quartile ranges (Med $\left(Q_{25} ; Q_{75}\right)$ ).

\section{References}

1. Xiong Y, Mahmood A, Chopp M. Current understanding of neuroinflammation after traumatic brain injury and cell-based therapeutic opportunities. Chin. J. Traumatol. 2018;21(3):137-151.

2. Celia A. McKee and John R. Lukens. T cells in the central nervous system: messengers of destruction or purveyors of protection? Immunology. 2014;(141):340-344.

3. O'Neil ME, Carlson K, Storzbach D, et al. Complications of Mild Traumatic Brain Injury in Veterans and Military Personnel: A Systematic Review. Washington (DC): Department of Veterans Affairs (US); 2013 Jan.

4. Kudryavtsev IV, Borisov AG, Krobinets II, et al. Chemokine receptors at distinct differentiation stages of T-helpers from peripheral blood. Medical Immunology (Russia). 2016;18(3):239-250. 